\title{
Jerusalem Artichoke (Helianthus Tuberosus L.) as A potential Chlorophyll Source for Humans and Animals Nutrition
}

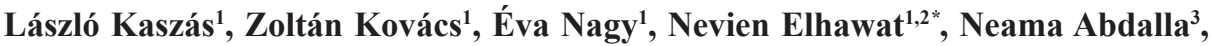 \\ Éva Domokos-Szabolcsy ${ }^{1}$ \\ ${ }^{1}$ Agricultural Botanics, Plant Physiology and Biotechnology Department, University of \\ Debrecen, AGTC Böszörményi u. 138, 4032 Debrecen, Hungary(Email: kaszaslacee@ \\ gmail.com; zoli.kovacs92@gmail.com; domokosszabolcsy@gmail.com) \\ ${ }^{2}$ Department of Biological and Environmental Sciences, Faculty of Home Economic, \\ Al-Azhar University,Egypt (nevienelhawat@gmail.com) \\ ${ }^{3}$ Plant Biotechnology Department, Genetic Engineering Division, National Research \\ Center, 33-El-Behouth Street, 12622 Dokki, Cairo,Egypt (E-mail: neama_ncr@yahoo. \\ com)
}

\begin{abstract}
CONSUMPTION of green leafy vegetables is thought to have great potentials on health promoting effects. In addition to different secondary metabolites, photosynthetic pigments have been proved antioxidant, anti-mutagenic, and detoxification activities. The current research was aimed to evaluate the vegetative part of seven ecotypes/varieties of Jerusalem artichoke (i.e., Alba, Fuza, Kalevala, Kercaszomori, Piri, Rubik, and Tápióisima) as a potential source for chlorophyll. Alfalfa (Hunor variety)was applied as a control. Open field experiment was carried out during spring season 2016 at Horticultural Demonstration Garden at the University of Debrecen, Hungary. Pigments were measured in intact leaves, green juice and fiber fraction of different Jerusalem artichoke ecotypes/varieties. Results verified that alfalfa had higher contents of different photosynthetic pigments in both intact leaves and green juice, while fiber fraction of Jerusalem artichoke ecotypes/varieties contained higher photosynthetic pigments contents. Among Jerusalem artichoke varieties, Piri ecotype had highest chlorophyll a (6.199 $\left.\mathrm{mg} \mathrm{g}^{-1} \mathrm{DM}\right)$, carotenoids (8.865 $\left.\mathrm{mg} \mathrm{g}^{-1} \mathrm{DM}\right)$ and xanthophyll (2.946 $\left.\mathrm{mg} \mathrm{g}^{-1} \mathrm{DM}\right)$ contents in fiber fraction than other varieties. In green juice fraction, highest contents of carotenoids and xanthophyll (1.752 and $0.709 \mathrm{mg} \mathrm{g}^{-1} \mathrm{DM}$, respectively) were corresponded to Rubic ecotype. Intact leaves of Tápióisima ecotype had the highest contents of chlorophyll $a$ and xanthophyll (8.478 and $2.977 \mathrm{mg} \mathrm{g}^{-1} \mathrm{DM}$, respectively) compared to other varieties. While Alba plants had the highest chlorophyll $b$ content in both leaves and fiber fraction $\left(2.307\right.$ and $3.184 \mathrm{mg} \mathrm{g}^{-1}$ $\mathrm{DM}$, respectively), Fuza ecotype recorded the highest content of chlorophyll $\mathrm{b}$ and carotenoids (1.042 and $4.042 \mathrm{mg} \mathrm{g}^{-1} \mathrm{DM}$, respectively) in green juice and leaves, respectively. However, these results revealed that green leaves of Jerusalem artichoke as it is or fractionated as green juice and fiber fractions are potential sources for chlorophyll and they can serve as alternative source for consumption chlorophyll.
\end{abstract}

Keywords: Jerusalem artichoke, Photosynthetic pigments, Chlorophyll a; Chlorophyll b; Carotenoids, Nutrition.

\section{Introduction}

Either by humans or animals, consumption of green leafy vegetables was reported to have beneficial effects on health due to alerting antioxidant, anti-mutagenic, and detoxification activities (Wang and Wink 2016). Large amounts of phytonutrients and nutraceuticals have been identified in green vegetables which helping the body in maintenance of health and fighting various disease (Mahima et al. 2014). Among phytonutrients, photosynthetic pigments are well known as a main constituent of leaves and stems. The major group of photosynthetic pigments is chlorophylls in plants, with two main different chemical forms, namely chlorophyll 'a' and ' $b$ ' (Haraszty 1978). 
The chlorophylls as 'green blood' are responsible for the green color of plants and they have essential role in photosynthesis. At the same time physiological impact of them for human health maintenance and prevention of chronic disease have also been attracted interest, recently. The structure of chlorophyll ' $a$ ' and ' $b$ ' are similar to the structure of hemoglobin, what can be found mostly in mammal's blood. The major difference between the chlorophyll and hemoglobin is their central atom, magnesium or iron (Kospell et al. 2005; Rao and Rao 2007).

Beneficial biological activities of natural chlorophylls and their derivatives have been widely investigated (Ferruzzi and Blakeslee 2007). Among other chlorophylls can be attributed positive effects on inflammation, oxidation processes wound healing (Inanc 2011), and control of calcium oxalate crystals formation (Tawashi et al. 1980). Chlorophyll and natural or commercial derivatives have demonstrated antioxidant activity, antimutagenic activity, modulation of xenobiotic metabolizing enzymes, and induction of apoptotic events in cancer cell lines in vitro and in vivo experiments (Ferruzzi and Blakeslee 2007). In addition, they have ability to induce mammalian phase 2 proteins which protect cells against deleterious effect of oxidants and electrophiles (Diwakar Gore et al. 2107). Protective effects of chlorophyll and their watersoluble salts (chlorophyllin) against consequence of carcinogen exposure like aflatoxin were also confirmed in animals. Along with this Egner et al. (2001) suggested the chlorophyll enriched food as an effective approach to chemoprevention.

Carotenoids as accessory pigments give the yellowish, red and orange colors of plants. It can transmit the light energy from the sun to chlorophylls, but they also have protective role because of their conjugated double bonds with delocalized $\pi$-electrons. These bonds can scavenge free oxygen radicals, and reduce oxidative stress in organisms (xanthophyll cycle).Carotenoids can be divided into two groups, the oxygen free carotenes and xanthophylls, which contain oxygen in different forms such as one or more hydroxy or epoxy groups. There are two isomers of the carotene, $\alpha$-carotene and $\beta$-carotene. $\beta$-carotene is the precursor of xanthophylls, zeaxanthin, violaxanthin and antheraxanthin (Lichenthaler 1987; Rao and Honglei 2002). In the previous century, Palmer (1915), underlined the photosynthetic pigments importance of nutrition

Env. Biodiv. Soil Security Vol.2 (2018) in poultry and cattle. His work highlighted that the deep yellow colour of laying hens egg yolks and their meat due to xanthophylls (lutein), and the typical colour of the milk of dairy cow duo to carotenes.

Jerusalem artichoke (Helianthus tuberosus L.) is a perennial plant, which commonly known as Jerusalem artichoke, or in Hungarian csicsóka. Nowadays growing interest has been directed towards Jerusalem artichoke due to its numerous uses (AbdAlla et al. 2014). Along with utilization in a biorefinery context has also been emerged of this plant (Domokos-Szabolcsy et al. 2015; Johansson et al. 2015).As vegetable, the most valuable part of Jerusalem artichoke is the tuber with high inulin content (Johansson et al. 2015). Among monosaccharides fructose and glucose are in smaller amount (Gunnarsson et al. 2014). According to Kim et al. (2013) the tubers contains $2-3 \%$ (dry weight) protein as well, however Johansson et al. (2015) wrote $5.3 \%-10.4 \%$. At the same time Jerusalem artichoke produces huge green biomass which is rich source of biomolecules such as proteins, volatile essential oils (mainly $\beta$-bisabolene and 17 other identified volatile compounds) polyacetylenic derivatives sesquiterpene compounds, phenolics, flavonoids and chlorophylls, carotenoids (Chen et al. 2013; Helmi et al. 2014; Pan et al.2009). These could be important not only for feedstock but for human nutrition/health as well (Duma et al. 2014). Despite the valuable green biomass, direct fresh consumption or dried preservation of Jerusalem artichoke is not preferable due to the spines and hairs covered leaves. Ensiling, appears to be the preferable one way to preserve fresh Jerusalem artichoke tops for a long time (Seiler1993; Razmakh et al. 2017). Alternatively, green biomass can be fractionated to soluble green juice and insoluble fiber fractions by pressing. The cell wall deprived green juice is easy to digest food product, with high amount of proteins. Besides proteins, green juice contains valuable carbohydrates, lipids, nutrients, antioxidants and chlorophylls (Fremery et al. 1971). Green juice is suitable for further production of leaf protein concentrate (LPC) using heat, solvents, acid and/ or salts precipitation. Because of the pressing process is not entire, significant amount not ruptured or partial ruptured cells remains in the fibre fraction with chlorophylls, cellulose, lignin and other cell wall components (Rawate and Hill 1985). In addition, the LPC contains a high amount of photosynthetic pigments and 
derivatives, as additional value from health aspect. Therefore, the aim of current work was to compare the photosynthetic pigments content of fractionated green biomass of several Jerusalem artichoke ecotypes.

\section{Materials and Methods}

\section{Experimental design}

The experiment was conducted at the Horticultural Demonstration Garden at the University of Debrecen in spring season 2016. Seven Jerusalem artichoke (Helianthus tuberosus L.) ecotypes/varieties were compared and alfalfa (Medicago sativa L.) 'Hunor' variety was used as a control (Table 1).

\section{Plant sampling and preparation}

The green biomass was harvested at the end of June when the young plants were around $1 \mathrm{~m}$ high. The photosynthetic pigments determination was conducted from the leaves directly, for this, 10 - 10 well-developed leaves from the upper third part of varieties were collected. At the same time, harvested biomass was separated into green juice and fiber using twin screw press machine. The fractionation method followed the Ereky process (Kaszás et al. 2016; Fári and Kralovánszky 2004), which was applied for leaf protein concentrate production. The photosynthetic pigment content was measured from intact leaves, green juice and fiber fractions as well.

TABLE 1. Names and origins of ecotypes/varieties of the tested plants.

\begin{tabular}{|c|c|c|c|}
\hline Plant type & Ecotype/ variety & \multicolumn{2}{|l|}{ Origin } \\
\hline \multirow{7}{*}{$\begin{array}{l}\text { Jerusalem artichoke } \\
\text { (Helianthus tuberosus L.) }\end{array}$} & Alba & \multicolumn{2}{|l|}{ Hungary, Debrecen region } \\
\hline & Fuza & \multicolumn{2}{|l|}{ Egypt } \\
\hline & Kalevala & \multicolumn{2}{|l|}{ Finland } \\
\hline & Kercaszomori & \multicolumn{2}{|c|}{ Hungary, NÖDIK Pannon seed bank } \\
\hline & Piri & \multicolumn{2}{|l|}{ Hungary, Téglás region } \\
\hline & Rubik & \multicolumn{2}{|c|}{ Hungary, NÖDIK Pannon seed bank } \\
\hline & Tápióisima & \multicolumn{2}{|c|}{ Hungary, NÖDIK Pannon seed bank } \\
\hline \multirow{2}{*}{\multicolumn{4}{|c|}{$\begin{array}{cc}\text { Alfalfa (Medicago sativa) } & \text { Hunor } \\
\text { For the photosynthetic pigments }\end{array}$}} \\
\hline & & & \\
\hline determination, the san & paration was & \multicolumn{2}{|c|}{ 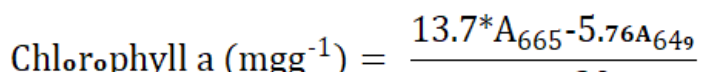 } \\
\hline \multicolumn{2}{|c|}{ performed as described by Duma et al. (2014). } & \multicolumn{2}{|c|}{ Chlorophyll a $\left(\mathrm{mgg}^{-1}\right)=\frac{\text { mass } * 200}{}$} \\
\hline \multicolumn{2}{|c|}{$\begin{array}{l}\text { For leat pigment extraction } 100 \mathrm{mg} \text { fresh plant } \\
\text { material was weighted and after then grinded }\end{array}$} & \multicolumn{2}{|c|}{ Chlorophyll b $\left(\mathrm{mgg}^{-1}\right)=\frac{25.8 * A_{649}-7.6 A_{665}}{}$} \\
\hline \multicolumn{2}{|c|}{$\begin{array}{l}\text { in mortal with little amount silica sand and } \\
1-3 \mathrm{~mL} 96 \% \text { ethanol was added. The mixture }\end{array}$} & \multicolumn{2}{|c|}{ mass $* 200$} \\
\hline \multirow{3}{*}{\multicolumn{2}{|c|}{$\begin{array}{l}1-3 \mathrm{~mL} 96 \% \text { ethanol was added. The mixture } \\
\text { was quantitatively transferred to test tube and } \\
\text { brought up to } 5 \mathrm{~mL} \text { with } 96 \% \text { ethanol. After } \\
\text { vigorous shaking it was incubated in dark place }\end{array}$}} & \multirow{2}{*}{\multicolumn{2}{|c|}{ Carotenoids $\left(\mathrm{mg} \mathrm{g}^{-1}\right)=\frac{4.7^{*} \mathrm{~A}_{480}-0.263 \mathrm{c}_{\text {chla-chlb }}}{m ? c^{*} 20 \mathrm{c}}$}} \\
\hline & & & mass*20n \\
\hline & $\begin{array}{l}\text { in dark place } \\
\text { tes. Last step }\end{array}$ & \multicolumn{2}{|c|}{ Xanthophylls (lutein) $\left(\mathrm{mg} \mathrm{g}^{-1}\right)=\frac{11.51^{*} \mathrm{~A}_{480} \cdot 20.61 \mathrm{~A} 495}{\text { mass } * 200}$} \\
\hline
\end{tabular}
(Eppendorf Centrifuge $5415 \mathrm{R}$ ). Same preparation procedures were applied for the leaves, green juice and fiber fraction pigment extraction.

\section{Photosynthetic pigments determination}

For measuring photosynthetic pigment content Ultraspec 2100 pro (Biochrom) spectrophotometer was used. The light absorbance was measured on five wavelengths i.e., $665 \mathrm{~nm}, 649 \mathrm{~nm}, 440 \mathrm{~nm}$, $480 \mathrm{~nm}$, and $495 \mathrm{~nm}$ according to Duma et al (2014).The resulting values were calculated with an appropriate formula as described by Duma et al. (2014) as follow:

The final data were corrected based on the dry mass (Table 2). Plant samples were lyophilized using Christ Alfa 1-4 LSC lyophilizer.

\section{Statistical analysis}

Experiments were done in 4 replicates mean values and standard errors were calculated in Microsoft Office Excel 2016. The obtained data was elaborated by ANOVA and Duncan multiple range test at $P<0.05$, using $\mathrm{R}$ Statistics packages.

\section{Results and Discussion}

Based on literatures not only the tubers but also areal part of Jerusalem artichoke can be valuable 
for animal feeding purpose. Present study focused on the quantification of photosynthetic pigments from Jerusalem artichoke leaves and fractionated green juice and fiber. Control was alfalfa as the most important green biomass for animal feeding.

\section{Photosynthetic pigments in leaves}

By comparing the different seven Jerusalem artichoke ecotypes/varieties and applying alfalfa as a control, significant differences were found of photosynthetic pigments in leaves (Fig. 1). The highest amount of chlorophyll $a$ was in the intact leaves of Jerusalem artichoke 'Tápióisima' ecotype ( $\left.8.478 \mathrm{mg} \mathrm{g}^{-1} \mathrm{DM}\right)$, while the alfalfa leaves had $9.423 \mathrm{mg} \mathrm{g}^{-1} \mathrm{DM}$, the other six ecotypes/varieties had almost the same values (6.013-7.800 $\mathrm{mg} \mathrm{g}^{-1} \mathrm{DM}$ ) (Fig. 1). Žnidarčič et al (2011) measured pigment content of five commonly consumed leafy vegetables; they found similar chlorophyll a value, except Cichoriumintybus'Anivip' (238.31 mg/100g) and Eruca sativa (261.24 mg/100g) which had higher values. The highest amount of chlorophyll $b$ in leaves was found in Alba (2.307 $\left.\mathrm{mg} \mathrm{g}^{-1} \mathrm{DM}\right)$ and Tápióisima (1.585 $\mathrm{mg} \mathrm{g}^{-1} \mathrm{DM}$ ) ecotypes. Values of the other five ecotypes were varied between 0.807 $1.249 \mathrm{mg} \mathrm{g}^{-1} \mathrm{DM}$, however alfalfa leaves had value of $3.852 \mathrm{mg} \mathrm{g}^{-1} \mathrm{DM}$. Regarding carotenoid content of leaves, data presented in Fig. 1 showed that the highest contents were measured in leaves of Fuza (4.042 $\mathrm{mg} \mathrm{g}^{-1} \mathrm{DM}$ ) and in Tápióisima (3.987 mg $\mathrm{g}^{-1} \mathrm{DM}$ ), while alfalfa leaves contained $5.361 \mathrm{mg}$ $\mathrm{g}^{-1}$ DM. Almost, similar values of carotenoids were obtained for other ecotypes/varieties (3.278$\left.3.432 \mathrm{mg} \mathrm{g}^{-1} \mathrm{DM}\right)$ expect Alba which had 2.771 $\mathrm{mg} \mathrm{g}^{-1} \mathrm{DM}$. Data of xanthophyll content depicted

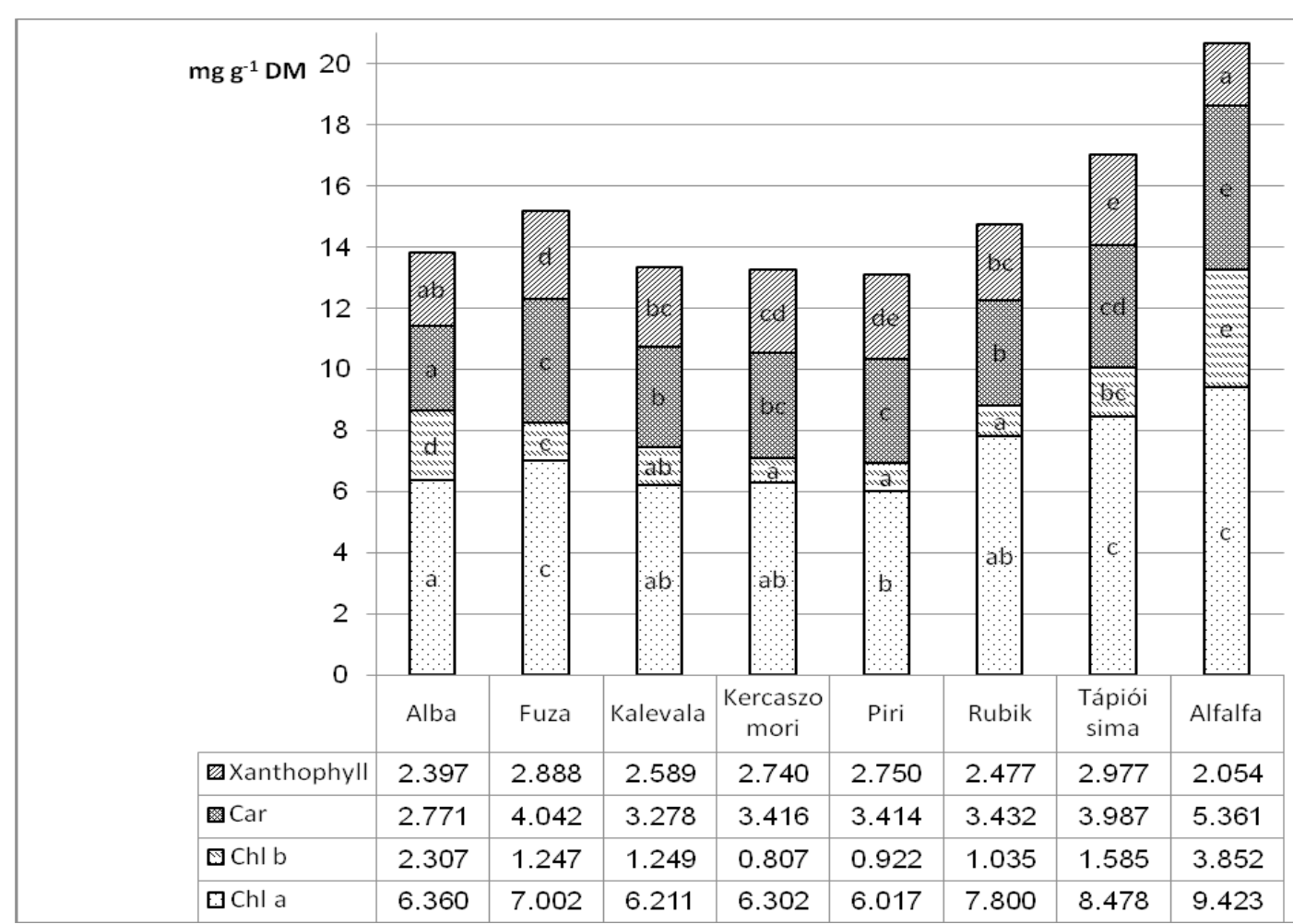

Fig. 1. Photosynthetic pigment content in leaves of Jerusalem artichoke ecotypes/varieties compared to alfalfa as a control (Means in the same column followed by the same letter are not significantly different according to Duncan's test at $P<0.05$ ).

in Fig. 1 showed that the higher values in the intact leaves were measured in Tápióisima $\left(2.977 \mathrm{mg} \mathrm{g}^{-1}\right.$ $\mathrm{DM})$ and Fuza (2.888 $\left.\mathrm{mg} \mathrm{g}^{-1} \mathrm{DM}\right)$ ecotypes. For other ecotypes/varieties, same values almost were measured and ranged from 2.397 to $2.589 \mathrm{mg} \mathrm{g}^{-1}$ DM.

Photosynthetic pigments in green juice

By examining the chlorophyll a content of green Env. Biodiv. Soil Security Vol.2 (2018) juices (Fig. 2), results proved that fractionated green juice contains lower chlorophyll a than intact leaves of tested ecotypes/varieties of Jerusalem artichoke. Among investigated ecotypes/varieties, we saw that the content of chlorophyll $a$ in green juices did not follow the tendency of the results in the leaves, expect 'Rubik' ecotype. Highest content was measured in 'Kalevala' $\left(3.067 \mathrm{mg} \mathrm{g}^{-1}\right.$ 
DM) and 'Rubik' (2.668mg g-1 DM) ecotypes, while $5.095 \mathrm{mg} \mathrm{g}^{-1} \mathrm{DM}$ was found in leaves of alfalfa. On the other hand, chlorophyll $b$ values in green juices extracted from green leaves were the highest in green juice derived from leaves of Fuza (1.042 $\left.\mathrm{mg} \mathrm{g}^{-1} \mathrm{DM}\right)$ and Tápióisima (1.030 $\left.\mathrm{mg} \mathrm{g}^{-1} \mathrm{DM}\right)$ ecotypes among all studied ecotypes/ varieties of Jerusalem artichoke, while control plant (alfalfa) had $1.725 \mathrm{mg} \mathrm{g}^{-1}$ DM. However, the low values of Alba (0.949 $\left.\mathrm{mg} \mathrm{g}^{-1} \mathrm{DM}\right)$ and Rubik (0.919 $\mathrm{mg} \mathrm{g}^{-1} \mathrm{DM}$ ) are considered not negligible either. By examining the carotenoid content of green juices, data showed that Alba and Rubik had similar values as 1.729 and $1.752 \mathrm{mg}$ $\mathrm{g}^{-1} \mathrm{DM}$, respectively.Data of xanthophyll content in green juice fraction showed that among all studied ecotypes/varieties of Jerusalem artichoke the highest content $\left(0.709 \mathrm{mg} \mathrm{g}^{-1} \mathrm{DM}\right)$ was found

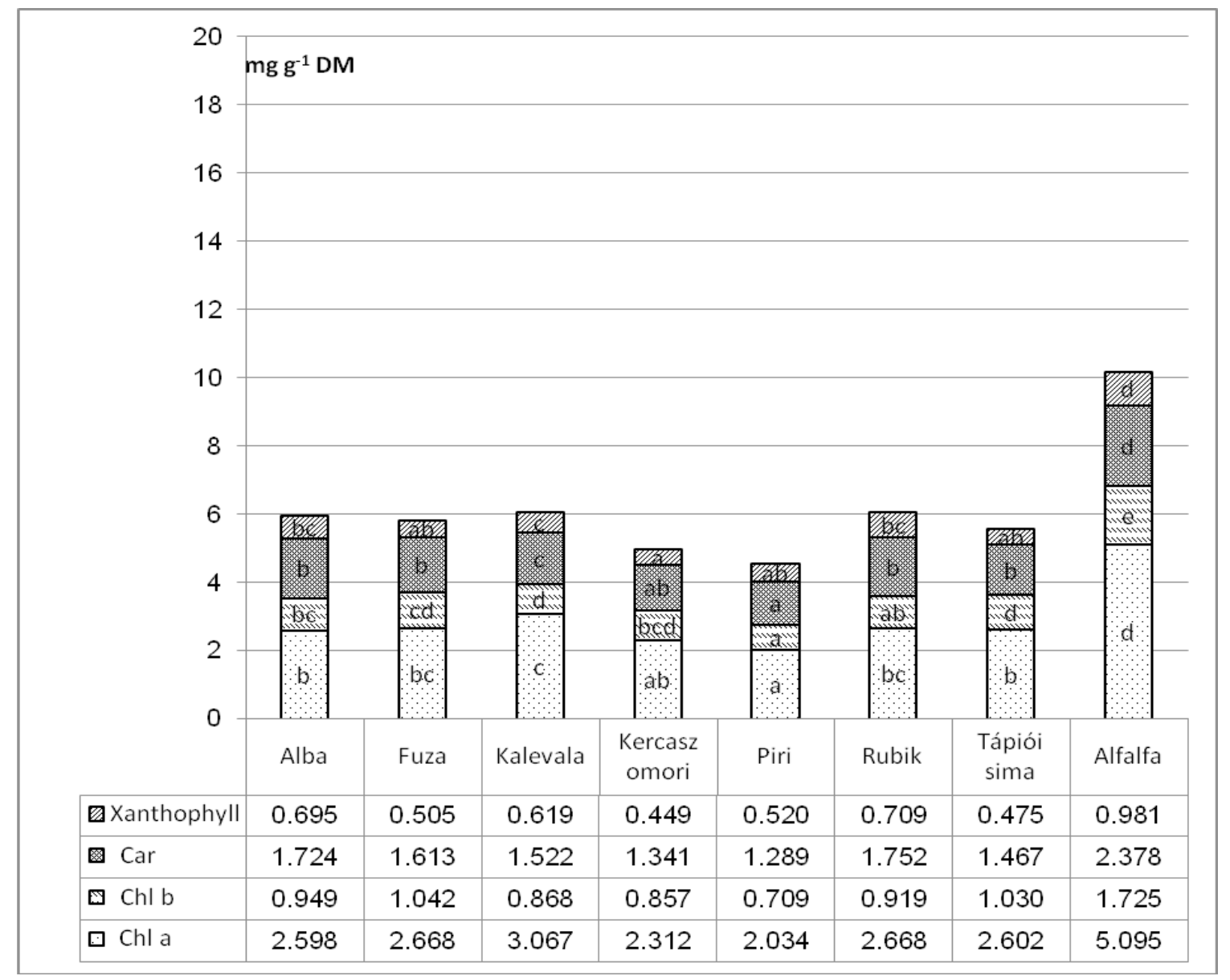

Fig. 2. Photosynthetic pigment content in green juices of Jerusalem artichoke ecotypes/varieties compared to alfalfa as a control (Means in the same column followed by the same letter are not significantly different according to Duncan's test at $P<0.05$ ).

in green juice extracted from leaves of Rubik ecotype followed by Alba ecotype $\left(0.695 \mathrm{mg} \mathrm{g}^{-1}\right.$ DM). However, these results were not far from those derived from green juice of alfalfa leaves which had $0.981 \mathrm{mg} \mathrm{g}^{-1}$ DM (Fig.2).

\section{Photosynthetic pigments in fiber fraction}

Regarding fiber fraction, results illustrated that the highest amount of chlorophyll a was measured in Alba (5.241 $\mathrm{mg} \mathrm{g}^{-1} \mathrm{DM}$ ) and in Tápióisima (5.312 $\left.\mathrm{mg} \mathrm{g}^{-1} \mathrm{DM}\right)$ ecotypes, while the lowest value (1.245 $\left.\mathrm{mg} \mathrm{g}^{-1} \mathrm{DM}\right)$ was recorded if fiber fraction of Rubik leaves. However, other ecotypes/ varieties had values ranged from 1.759 to $3.812 \mathrm{mg} \mathrm{g}^{-1} \mathrm{DM}$ and alfalfa (control) had $2.351 \mathrm{mg} \mathrm{g}^{-1}$ DM (Fig.3). Content of chlorophyll $b$ in fiber fraction was the highest in Alba (2.449 $\left.\mathrm{mg} \mathrm{g}^{-1} \mathrm{DM}\right)$ followed by Tápióisima $(2.284 \mathrm{mg}$ $\left.\mathrm{g}^{-1} \mathrm{DM}\right)$, while in alfalfa chlorophyll $b$ was 1.367 mg $\mathrm{g}^{-1}$ DM. Other ecotypes/varieties showed varied values of chlorophyll $b$ but the lowest value $\left(0.475 \mathrm{mg} \mathrm{g}^{-1} \mathrm{DM}\right)$ was corresponded to 
Rubic ecotype.Alba ecotype had the highest content $\left(2.667 \mathrm{mg} \mathrm{g}^{-1} \mathrm{DM}\right)$ of carotenoids in fiber fraction followed by Tápióisima $\left(2.750 \mathrm{mg} \mathrm{g}^{-1}\right.$ DM), meanwhile control plant (alfalfa) had lower carotenoids content $\left(1.355 \mathrm{mg} \mathrm{g}^{-1} \mathrm{DM}\right)$. The lowest content among all ecotypes/varieties was denoted for Rubic ecotype which had $0.804 \mathrm{mg}$ $\mathrm{g}^{-1}$ DM. However, other ecotypes had carotenoids contents varied from 1.239 to $1.954 \mathrm{mg} \mathrm{g}^{-1} \mathrm{DM}$. In the case of xanthophyll, these two ecotypes (Alba

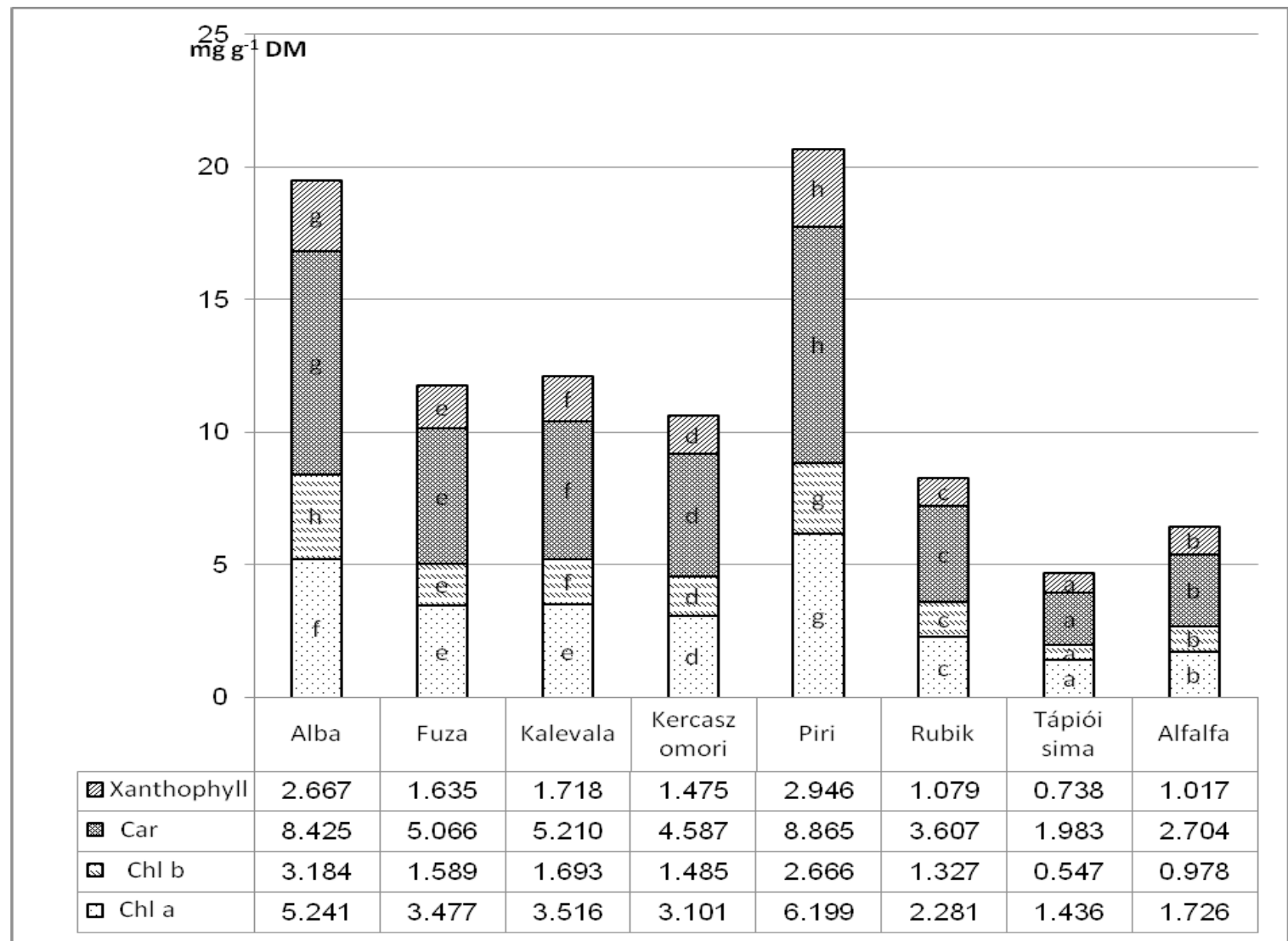

Fig. 3. Photosynthetic pigment content in fibers of Jerusalem artichoke ecotypes/varieties compared to alfalfa as a control (Means in the same column followed by the same letter are not significantly different according to Duncan's test at $P<0.05$ ).

and Tápióisima) are also worth mentioning, but Kercaszomori (1.020 mg g-1 DM) also showed good results. In general, the Rubik ecotype did not show any similarity to any of the other Jerusalem artichokes related to xanthophyll content in fiber fraction (Fig.3).

Chlorophylls are known to be easily degraded by such as dilute acids, heat and oxygen (Tonucci and Von Elbe 1992). The reason for green color loss during processing is mainly attributed to the conversion of chlorophylls to pheophytins by the influence of pH (Mingues-Mosquera et al. 1989). In acid medium, magnesium in the chlorophyll rings is replaced by two hydrogen ions and green chlorophylls are converted to the olive brown pheophytins (Mangos and Berger 1997; Van Bokel 1999; VanBokel 2000). In our current research $\mathrm{pH}$ of green juices ranged from 5.53 to Env. Biodiv. Soil Security Vol.2 (2018)
6.54.Formation of pheophytins is initiated by the release of cellular acids and the synthesis of new acids. It is reported that formation of pheophytin in processed vegetables is increased at lower tissue $\mathrm{pH}$ values and at higher process temperature (LaBorde and Von Elbe 1990). Likepheophytins, pheophorbides also may occur under the influence of heat or acid (Weemaeset al.1999). The cleavage of phytol chain of chlorophyll by the enzyme chlorophyllase results in formation of chlophyllide (Heaton and Marangoni 1996). In the presence of acid, chlorphyllides undergo loss of magnesium and form pheophorbides (Heaton and Marangoni 1996; White et al. 1963). The chlorophyllase activity also depends on the $\mathrm{pH}$ level and ionic content of the medium which thought to be involved in turnover and homeostasis of chlorophyll. The chlorophyllase 
also considered the firs enzyme in the chlorophyll degradation pathway. The location of the enzyme is the inner envelope membrane of the chloroplast (Matile et al. 1997).

Chlorophyll $b$ degradation is different from chlorophyll $a$, where chlorophyll $b$ is degraded by first being converted to Chlorophyll a (Ito et al. 1993; Schuermann et al. 1996).The second major problem during the processing is the high amount of polyphenols, which can cover the pigments. The main phenolic acids in $H$. tuberosus leaves are chlorogenic acids (93\%) (Chen et al. 2014; Yuan et al. 2012).More broadly, phenolic acids are wildly distributed in plants as the secondary metabolites (Mattila and Hellström 2007).According to Chen et al. (2014) the major phenolic compounds are 3-o-caffeoylquinic acid (33\%), 4,5-dicaffeoylquinic acid (24\%) and 3,5-dicaffeoylquinic acid $(21 \%)$ of the total phenolics.In addition, the dry matter content may also affect the photosynthetic pigment content. Different fractions yielded the following results: for leaves it represents around $20 \%$, green juices are around $11.5 \%$, fiber dry matter content is $40 \%$.

\section{Conclusion}

Alongside high tuber yield, Jerusalem artichoke generated a huge green biomass during its growing season rich in chlorophylls and carotenoids subsequently considerable amounts of chlorophylls and carotenoids for humans and animals consumption can be extracted in costeffective approach. The recent experiment studied the composition of photosynthetic pigments of seven ecotypes/varieties of Jerusalem artichoke as a potential source for chlorophyll. Alfalfa the main fodder crop - was applied as a control. Despite, alfalfa plants had the highest contents of chlorophyll a, chlorophyll b, carotenoids and xanthophyll compared to Jerusalem artichoke ecotypes/varieties particularly in intact leaves and green juice extracted by pressing; Jerusalem artichoke ecotypes/varieties had highest contents of photosynthetic pigments in fiber fraction. Also, resulted verified that Piri, Tápióisima, Alba and Rubic are the best among other studied ecotypes/ varieties. It could be concluded that Jerusalem artichoke green biomass (especially leaves) can a good and rich source of chlorophyll for animal. Along with it spines and fibres free, easy to digest green juice with significant amount of valuable photosynthetic pigments can also be good raw material for further food development involving inhuman nutrition.

\section{Acknowledgments}

This research was supported by the European Union and the State of Hungary, co-financed by the European Social Fund in the framework of TÁMOP-4.2.4.A/2-11/1-2012-0001'National Excellence Program'. Also, this current work was co-financed by Tempus Public Foundation (TPF), Hungary.

\section{References}

Abd Alla N., Domokos-Szabolcsy, É., El-Ramady H., Hodossi S., Fári M., Ragab M. and Taha H. (2014) Review of In vivo and in vitro propagation. Int. J. Hort. Sci 20 (3-4), 131 - 136

Anu Rahal, Mahima, Amit Kumar Verma, Amit Kumar, Ruchi Tiwari , Sanjay Kapoor, Sandip Chakraborty and Kuldeep Dhama (2014) phytonutrients and nutraceuticals in vegetables and their multi-dimensional medicinal and health benefits for humans and their companion animals: A review. Journal of Biological Sciences, 14, 1-19.

Chen, F., Long, X., Lin, Z., Shao, H., Liu, L. (2014) Analysis of phenolic acids of Jerusalem artichoke (Helianthus tuberosus L.) responding to saltstress by liquid chromatography/tandem mass spectrometry. doi:10.1155/2014/568043.

Domokos-Szabolcsy, É., Abdalla N, El-Ramady H., Kaszás L., Hodossi S. (2015) A csicsókában (Helianthus Tuberosus L.) rejlő lehetőségek a biofinomító ipar korszakában Kertgazdaság 47(3), 3-11.

Duma, M., Alsina, I., Zeipina, S., Lepse, L., Dubova, L. (2014) Leaf vegetables as sourse of phytochemicals. Foodbalt. 2014, 262-265

Fári M. and Kralovánszky U. P. (2004) Az Erekyrejtély megoldása: a "biotechnológia" első fogalma Magyarországon in A honi Kopernikusz-recepciótól a magyar Nobel-díjakig. Szerk: Palló G., Budapest, p. $240-268$.

Ferruzzia, M. and Blakeslee, J. (2007) Digestion, absorption, and cancer preventative activity of dietary chlorophyll derivatives. Nutrition Research 27, $1-12$

Fremery de D.; Bickoff, E. M.; Kohler G., O. (1971) The development of alfalfa leaf protein concentrates for human and animal uses. $1^{\text {st }}$ Californian Alfalfa Symposium 33-38.

Fujia Chen a,b,1, Xiaohua Long a,1, Mengni Yu a, Zhaopu Liu a, Ling Liu a and Hongbo Shao (2013) 
Phenolics and antifungal activities analysis in industrial crop Jerusalem artichoke (Helianthus tuberosus L.) leaves. Industrial Crops and Products 47 (2013) 339-345.

Gasperini, L. and C. Maguire, (2001) Targeting the Rural poor: The role of education and training. Sustainable Development, Food and Agriculture Organization of the United Nations. http://www. fao/sd/2002/kn0301a_en.htm

Gunnarsson, I.B., Svensson, S.E., Johansson, E., Karakashev, D. and Angelidaki, I. (2014) Potential of Jerusalem artichoke (Helianthus tuberosus L.) as a biorefinery crop. Ind. Crops Prod. 56, 231-240

Haraszty, Á. (1978) Növényszervezettan és élettan. Nemzeti Tankönyvkiadó, Budapest ISBN: 963, 18, 84694

Heaton, W.J. and Marangoni, A.G. (1996) Chlorophyll degradation in processed foods and senescent plant tissues. Trends in Food Science and Technology. 1996. Vol 7. 8-15.

Ito, H., Tanaka, Y., Tsuji H. and Tanaka, A. (1993) Conversion of chlorophyll 'b' to chlorophyll 'a' by isolated cucumber etioplasts. Archives of Biochemistry and Biophysics. 306,148-151.

Johansson, E., Prade T., Angelidaki I., Svensson S-E., Newson W. R., Gunnarsson I.B. and Hovmalm H.P. (2015) Economically Viable Components from Jerusalem Artichoke (Helianthus tuberosus L.) in a Biorefinery Concept Int. J. Mol. Sci. 2015, 16, 8997-9016; doi:10.3390/ijms16048997

Kaszás, L., Fári, M., Hodossi, S. and DomokosSzabolcsy É. (2016) Levélfehérje-vizsgálatok a csicsóka leveles hajtásának hasznosítása érdekében. Acta Agraria Debreceniensis 67,43-47.

Kays, S.J. and Notthingham, S.F. (2008) Biology and Chemistry of the Jerusalem Artichoke Helianthus tuberosus L., CRC Press, ISBN 1-4200-4495-8

Kim, S. and Dale, B.E. (2004) Global potential bioethanol production from wasted crops and crop residues, Biomass and Bioenergy 26 (2004) 361375 .

Kim, S., Park, J.M. and Kim, C.H. (2013) Ethanol Production Using Whole Plant Biomass of Jerusalem Artichoke by Kluyveromyces marxianus CBS1555 Appl Biochem Biotechnol. 169, 15311545

Kospell D.A., Kospell D.E. and Curran-Celentano J. (2005) Carotenoid and chlorophyll pigment in sweet basil grown in the field and greenhouse. Hort Science, 40 (5), 1230-1233.

La Boede, L.F. and Von Elbe J. H. (1990) Zinc complex formation in heated vegetable purees. J. Agric. Food Chem. 38, 484-487.

Latharn, M.C. (1997) Human Nutrition in the Developing World. Food and Agricultural Organization of the United Nations. Rome, Italy, ISBN-10: $925103818 \mathrm{X}$ pp: 522.

Levent İnanç (2011) Chlorophyll: Structural Properties, Health Benefits and Its Occurrence in Virgin Olive Oils. Akademik Glda 9(2), 26-32

Lichtenthaler, H.K. (1987) Chlorophylls and Carotenoids: Pigments of Photosyntetic Biomembranes. Methods in Enzymathology, 148, 350-382.

M. Razmkhah, J. Rezaei, H. and Fazaeli PII (2017) Use of Jerusalem artichoke tops silage to replace corn silage in sheep diet. Animal Feed Science and Technology DOI: http://dx.doi.org/doi:10.1016/j. anifeedsci.2017.04.019

Mangos, T.J. and Berger R.G. (1997)Determination of major chlorophyll degradation products. Z. Lebens. Unters. Forsch. A. 204,345-350.

Martile P., Schellenberg M. and Vicentin, F. (1997) Localization of chlorophyllase in the chloroplast envelope. Planta 201,96-99.

Mattila P. and Hellström, J. (2007) Pheniloc acids in potatoes, vegetables, and some of there products. Journal of Food Composition and Analysis. 20(34),335-338.

Mingues-Masquera, M.J., Garrido-Fernandez and Gandul-Rojas, B. (1989) Pigment changes in olives during fermentation and brine store. J. Agric. Food Chem. 37,8-11.

Palmer, L.S. (1915) Xhantophyll the principal natural yellow pigment of the egg yolk, body fat, and blood serum of hen. The physiological relation of the pigment to the xanthophyll of plants. Journal of Biological Chemistry 23,261-279.

Pan L., Sinden M.R., Kennedy A.H., Chai H., Watson L.E., and Graham, T.L. (2009) Bioactive constituents of Helianthus tuberosus L. (Jerusalem artichoke). Phytochem Lett 2(1),15-8.

Prabhu, D.R. and Hill, R.M. (1985) Extraction of a high-protein isolate from Jerusalem artichoke (Helianthus tuberosus) tops and evaluation of its

Env. Biodiv. Soil Security Vol.2 (2018) 
nutrition potential. J. Agric. Food Chem., 33 (1), pp 29-31.

Rao, A.V. and Rao, L.G. (2007) Carotenoids in human health. Pharmacological Research 55, 207-216.

Rao, A.V. and Honglei, S. (2002) Effect of low dose lycopene intake on lycopene bioavailability and oxidative stress. Nutr. Res., 22,1125-1131.

Schumann V., Ito, H., Tanaka, A., Schoch, S. and Rudiger, W. (1996) Substrate specificaty of chlorophyll (ide) 'b' reductase in etioplasts of barley (Hordeum vulgare L.) European Jurnal of Biochemistry, 242,163-170.

Seiler. G. J. (1993) Forage and tuber yields and digestibility of selected wild and cultivated genotypes of Jerusalem artichoke. Agron. J. 85, 29-33.

Tawashi, R, Cousineau, M. and Sharkawi, M. (1980) Effect of sodium copper chlorophyllin on the formation of calcium oxalate crystals in rat kidney. Invest Urol 18, 90 - 2

Tonucci L.H. and Von Elbe J.H. (1992) Kinetics of the formation of zinc complexes of chlorohyll derivates. J. Agric. Food Chem. 40, 2341-2344.

Van Bokel MAJS (1999) Testing of kinetic models: usefulness of the multiresponse approach as applied to chlorophyll degradation in foods. Food. Res. Int. 32, 261-269.

Van Bokel MAJS (2000) Kinetic modelling in food science: case study on chlorophyll degradation in olives. J. Sci. Food Agric. 80, 3-9.
Wang and Wink (2016) Chlorophyll enhances oxidative stress tolerance in Caenorhabditis elegans and extends its lifespan. Peer J 4, e1879; DOI 10.7717/ peerj. 1879

Weemaes, C., Ooms, V., Van Loey, A.M. and Hendrickx, M.E. (1999) Kinetics of chlorophyll degradation and color less in heated broccoli juice. J. Agric. Food Chem. 47, 2404-2409.

White R.C., Jones J.D. and Gibbs E. (1963) Determination of chlorophylls, chlorophyllds, pheophytins and phephorbides in plant material. J. Food Sci. 28, 431-436.

Yuan, X., Gao, M., Xiao, H., Tan, C. and Du, Y. (2012) Free radical scavanging activities and bioactives and bioactive substances of Jerusalem artichoke (Helianthus tuberosus L.) leaves. Food Chemistry 133(1), 10-14.

Zead H, Mohammad K, Azzam A, Tsymbalista Y, Abo Ghazleh R, Shaibah, H. and Aboul-Enein H.(2014) Analysis of Essential Oil in Jerusalem Artichoke(Helianthustuberosus L.) Leaves and Tubers by Gas Chromatography-Mass Spectrometry Adv Pharm Bull, (Suppl2), 521-526 doi: 10.5681/ apb.2014.077

Žnidarčič, D., Ban, D. and Šircelj, H. (2011) Carotenoids and chlorophyll composition of commonly leafy vegetables in Mediterranean countries. Food Chemistry 129, 1164-1168.

Diwakar Gore, R., Palaskar, S.J. and Bartake A.R. (2017) wheatgrass: green blood can help to fight cancer. JClin Diagn Res. 11(6),40-42 doi: 10.7860/ JCDR/2017/26316.10057

(Received 16/2/2018; accepted 25/2/2018) 